ISSN 0258-7122

Bangladesh J. Agril. Res. 40(4): 693-702, December 2015

\title{
DEVELOPMENT OF UNION LEVEL DIGITAL DATABASES AND MAPS OF MAIZE GROWING AREAS AT PIRGONJ IN THAKURGAON DISTRICT
}

\author{
M. A. UDDIN ${ }^{1}$, K. S. RAHMAN ${ }^{2}$, M. M. RAHMAN ${ }^{3}$ \\ N. MOHAMMAD ${ }^{4}$ AND A. F. M. TARIQUL ISLAM ${ }^{5}$
}

\begin{abstract}
A study was conducted during 2012-13 to build union level digital databases and maps of maize growing areas using both primary and secondary data. Primary data were collected from maize growing areas of the upazilla namely Pirgonj of Thakurgaon district. For summer and winter maize; union, upazila, district and country level digitized maps were used in the study. Geographical Information System (GIS), Global Positioning System (GPS) and Management Information System (MIS) related Information Technology (IT) were also applied. Total cultivable land 28138 ha in Pirgonj upazila and area and production of maize were 5100 ha and 34508.75 t respectively. Sixteen (16) varieties were cultivated in the study areas and maximum area $(74.09 \%)$ of maize was cultivated by the executive varieties NK40, Pacific 984, 900M Gold, 900M, 3396, and Supergold. Average maize yield of the study areas was $6.77 \mathrm{t} / \mathrm{ha}$ during 2012-13. A web site was developed for variety wise area coverage data collection of maize as well as for other crops. This web site can also be used in mobile phone.
\end{abstract}

Keywords: Maize, Area, Cultivation, Production, Variety, Union, ICT and Digital database.

\section{Introduction}

Agriculture is the backbone of the nation but agricultural land is the scarcest means of production in Bangladesh. To overcome this situation, agricultural lands should be utilized more efficiently through cultivating high yielding crops like maize. Maize is playing an important role in the economy of Bangladesh. The area under maize cultivation is increasing day by day due to high demand. Thakurgaon districtis the third highest maize production area (28315ha) in Bangladesh.We selected Pirgonj upazila which is maximum yield production of maize at all upazilas in Thakurgaon district. Besides, the genetic yield potential of maize is also very high. There is an important scope of increasing the current yield and production in the country. Maize can be used as food for ensuring food security presently as well as in future increasing population of the country.

${ }^{1}$ Chief Scientific Officer, ASICT Division, Bangladesh Agricultural Research Institute (BARI), Gazipur-1701, ${ }^{2-5}$ Scientific Officer, ASICT Division, BARI, Gazipur-1701, Bangladesh. 
In terms of area, maize holds rank $3^{\text {rd }}$ followed by rice and wheat. Because of higher nutritional status, it could be a good source of nutrients for mal-nourished people in Bangladesh. It is now widely used in the poultry farms as animal feed, as well as the people consume roasted and fried maize in Bangladesh. Moreover, as a food item, maize is used in different forms such as maize flour, maize flour mixed with wheat flour etc. (Roy, 2009).

Due to wide adaptability, maize is grown in the varied environmental conditions in Bangladesh, from sub-tropical low land at sea level to high elevation. Potentiality for growing maize is high in almost throughout Bangladesh. So, it is under cultivation both in winter and summer season and well suited to the existing agronomic conditions, particularly rain fed condition.

Bangladesh Agricultural Research Institute (BARI) has been conducting research activities for varietal development of maize since 1976. Initially, thrust was given for development of composite varieties. So far, BARI developed 19 varieties among them eight open pollinated and 11 hybrid varieties. The yield potentiality of the released composite varieties varies from 5.5 to $7.0 \mathrm{t} / \mathrm{ha}$ and that of the hybrid varieties ranges $7.4-12.0$ t/ha. Status of those varieties in the farmers' field demands through investigation.

Now a day of ICT, it is necessary to build a IT based system for data collection of maize from root level. This system might be used for all other crops. It would be used for data collection of summer and winter maize from upazila, union even block level. By using ICT, collection, documentation of different information and preparation of maps can be done. So, the study was done with the following objectives:

(1) To determine the variety wise area coverage of maize in block, union, upazila and district.

(2) To develop a system for data collection, documentation and mapping of maize.

(3) To develop a database using GIS, GPS and MIS on the basis of IT.

\section{Materials and method}

Both primary and secondary data were used in the study. For primary data, two field surveys were done for summer and winter maize during 2012-13. Sites was selected purposively at Pirganj upazila of Thakorgaon district. Simple random sample procedure was followed for data collection and complete enumerations of different varieties of maize were taken for whole population. 
Primary data were collected as follows:

1. Summer and winter maize data were collected from maize growers of different upazilas by Sub Assistant Agriculture Officers (SAAO) during 2012-13.

2. Collected data were recorded by the concerned researcher from SAAO as per prescribed database structure.

3. The data schedule was filled up by UAO/SAAO and passed through internet.

4. At the time of data collection, GPS technology was used.

5. A web site was developed which was used through mobile phone for data collection.

The online data collection system through dedicated web portal is www.asictbari.net

Secondary sources were NGOs and GOs such as Soil Resources Development Institute (SRDI), Bangladesh Bureau of Statistics (BBS) and Department of Agricultural Extension (DAE) as well as (FAO). Statistical package program SPSS and Excel were applied in addition to Arc View GIS program and digitized maps of union, upazila, district and country were utilized in this study.

Table-1. Indexing on area, production and yield of maize cultivation in Bangladesh.

\begin{tabular}{|c|c|c|c|c|c|c|c|c|c|c|}
\hline Year & \multicolumn{2}{|r|}{ Area (ha) } & \multirow[t]{2}{*}{$\begin{array}{c}\text { Production } \\
(\mathbf{t})\end{array}$} & \multirow[t]{2}{*}{$\begin{array}{l}\text { Yield } \\
\text { (t/ha) }\end{array}$} & \multicolumn{3}{|c|}{$\begin{array}{c}\text { Indexing on the } \\
\text { basis of base year }\end{array}$} & \multicolumn{3}{|c|}{ Status (base year) } \\
\hline \multicolumn{3}{|c|}{ 1969-70 Base year line } & & & Area & Prod. & Yield & Area & Prod. & Yield \\
\hline $1969-70$ & & 3239 & 3000 & 0.93 & 100 & 100 & 100 & 1 & 1 & 1 \\
\hline $1974-75$ & 1 & 2834 & 2000 & 0.71 & 87.5 & 66.7 & 76.2 & 0.9 & 0.7 & 0.8 \\
\hline $1979-80$ & 2 & 2024 & 1000 & 0.49 & 62.5 & 33.3 & 53.3 & 0.6 & 0.3 & 0.5 \\
\hline $1984-85$ & 3 & 3644 & 3000 & 0.82 & 112.5 & 100 & 88.9 & 1.1 & 1 & 0.9 \\
\hline $1989-90$ & 4 & 3239 & 3000 & 0.93 & 100 & 100 & 100 & 1 & 1 & 1 \\
\hline 1994-95 & 5 & 2713 & 2680 & 0.99 & 83.8 & 89.3 & 106.7 & 0.8 & 0.9 & 1.1 \\
\hline 1999-00 & 6 & 3162 & 4075 & 1.29 & 97.6 & 135.8 & 139.1 & 1 & 1.4 & 1.4 \\
\hline $2005-06$ & 7 & 98447 & 521525 & 5.3 & 3039.6 & 17384 & 571.9 & 30.4 & 173.8 & 5.7 \\
\hline $2007-08$ & 8 & 223886 & 1346000 & 6.0 & 6912.2 & 44866.7 & 646.5 & 69.1 & 448.7 & 6.5 \\
\hline 2008-09 & 9 & 174000 & 1137000 & 6.53 & 5372.3 & 37900 & 705.5 & 53.7 & 379 & 7.1 \\
\hline $2009-10$ & 10 & 230000 & 1435000 & 6.24 & 7101.3 & 47833 & 673.6 & 71 & 478.3 & 6.7 \\
\hline $2010-11$ & 11 & 2,27060 & 15,52267 & 6.84 & 7010.2 & 51742 & 735.5 & 70 & 517.4 & 7.3 \\
\hline $2011-12$ & 12 & 2,87243 & 19,86879 & 6.92 & 8868.3 & 66229 & 744.1 & 88.7 & 662.3 & 7.4 \\
\hline $2012-13$ & 13 & 3,12566 & 21,83183 & 6.98 & 9650.08 & 72772.77 & 750.54 & 96.5 & 727.7 & 7.5 \\
\hline
\end{tabular}

Source: B.B.S. and DAE. 
In 1969-70, area of maize was 3239 ha and production was $3000 \mathrm{t}$ preindependence whereas in 2012-13 those were 312566 ha and 2183183 t, respectively. After 44 years, area, production and yield of maize were increased 96.5, 727.7 and 7.5 times respectively (Table-1).

Table- 2. Indexing on availability of maize crop in Bangladesh (base year1969-70).

\begin{tabular}{l|c|c|c|c|c|c}
\hline \multirow{2}{*}{ Year } & \multirow{2}{*}{ Sl. No } & \multirow{2}{*}{ Population } & \multirow{2}{*}{ Production (t) } & \multicolumn{3}{|c}{ Maize Availability } \\
\cline { 5 - 7 } & & & & $(\mathbf{k g} / \mathbf{h} / \mathbf{y})$ & $(\mathbf{g} / \mathbf{h} / \mathbf{m})$ & $(\mathbf{g} / \mathbf{h} / \mathbf{d})$ \\
\hline $1969-70$ & & 69882512 & 3000 & 0.04 & 3.58 & 0.12 \\
$1974-75$ & 1 & 78328571 & 2000 & 0.03 & 2.13 & 0.07 \\
$1979-80$ & 2 & 87981429 & 1000 & 0.01 & 0.95 & 0.03 \\
$1984-85$ & 3 & 98529274 & 3000 & 0.03 & 2.54 & 0.08 \\
$1989-90$ & 4 & 109300867 & 3000 & 0.03 & 2.29 & 0.08 \\
$1994-95$ & 5 & 118885011 & 2680 & 0.02 & 1.88 & 0.06 \\
$1999-20$ & 6 & 128172293 & 4075 & 0.03 & 2.65 & 0.09 \\
$2004-05$ & 7 & 136314875 & 521525 & 3.83 & 318.82 & 10.63 \\
$2007-08$ & 8 & 141028719 & 1343444 & 9.53 & 793.84 & 26.46 \\
$2008-09$ & 9 & 142600000 & 1137000 & 7.97 & 664.45 & 22.15 \\
$2009-10$ & 10 & 144171281 & 1435000 & 9.95 & 829.45 & 27.65 \\
$2010-11$ & 11 & 145759875 & 1552267 & 10.65 & 887.45 & 29.58 \\
$2011-12$ & 12 & 152518015 & 19,86879 & 13.03 & 1085.60 & 36.19 \\
$2012-13$ & 13 & 156194958 & 2183183 & 13.98 & 1164.77 & 38.83 \\
\hline
\end{tabular}

Source: Population census of Bangladesh, B.B.S. and DAE.

In 1969-70, maize crop availability was $0.12 \mathrm{~g} / \mathrm{h} / \mathrm{d}$ but in 2013 it was $38.83 \mathrm{~g} / \mathrm{h} / \mathrm{d}$ including seed and wastage (Table-2). 
DEVELOPMENT OF UNION LEVEL DIGITAL DATABASES

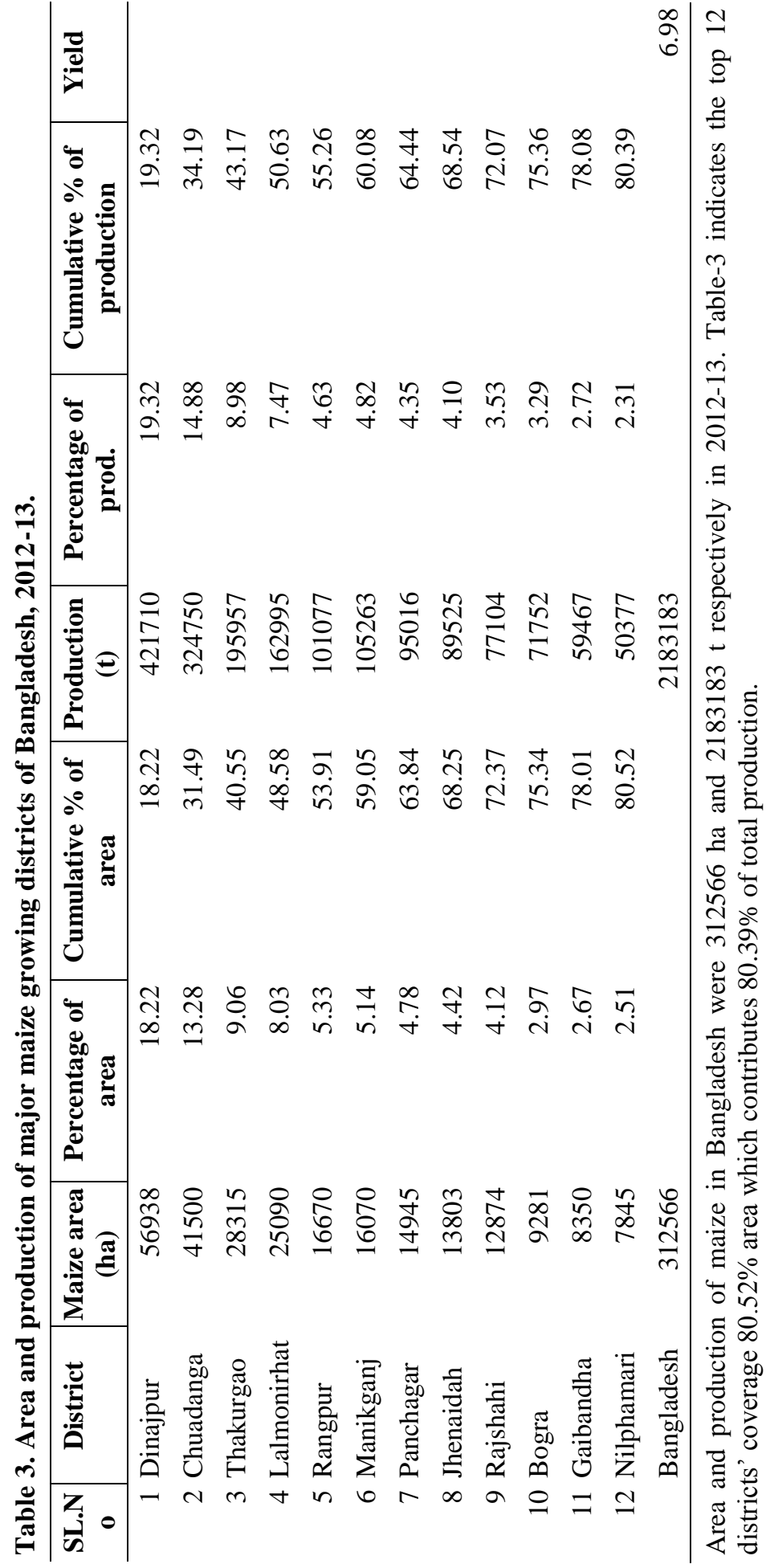




\section{Results and discussion}

In total, there were 20 blocks under 10 unions in the upazila Pirganj of Thakurgaon districts, (Table-4). Different agricultural information of maize production under the upazila was noted below:

Table 4. Blocks, unions and cultivable lands Pirganj upazila in Thakurgaon district, respectively in 2012-13.

\begin{tabular}{l|c}
\hline \multicolumn{1}{c|}{ Upazila } & $\begin{array}{c}\text { Pirganj } \\
\text { (Thakurgaon) }\end{array}$ \\
\hline Block & 20 \\
Union & 10 \\
Cultivable land (ha) & 28,138 \\
\hline
\end{tabular}

Source: Survey data of maize growers, 2012-13 collected by SAAO, DAE/Researcher, BARI.

Data were collected from the maize growers of the targeted upazila regarding cultivable land, area production, as well as yield of the crop. Databases of cultivable land, area, production and yield of maize in 2012-13 were prepared according to district, upazila and union.

Table 5. Union wise area (ha), production ( $t$ ) and yield ( $t / h a)$ of maize at Pirganj, Thakurgaon, 2012-13

\begin{tabular}{lcccc}
\hline Union & Area (ha) & Production (t) & Yield(t/ha) \\
\hline Bhamradeha & 380 & 2806.25 & 7.38 \\
Koharani ganj & 660 & 4083 & 6.19 \\
Khangaon & 260 & 1680 & 6.46 \\
Suaidpur & 410 & 3050 & 7.44 \\
Pirganj & 320 & 2590 & 8.09 \\
Hagipur & 725 & 4705 & 6.49 \\
Dalatpur & 215 & 1585.5 & 7.37 \\
Sengaon & 330 & 3251 & 9.85 \\
Jabarhat & 350 & 2673 & 7.64 \\
Burchuna & 1450 & 8085 & 5.58 \\
\hline Total & 5100 & 34508.75 & 6.77 \\
Average & 510 & 3450.87 & - \\
Max & 1450 & 8085 & 9.85 \\
Min & 215 & 1585.5 & 5.58 \\
Std & 368.60 & 1886.37 & 1.19 \\
Cv\% & 72.27 & 54.66 & 16.45 \\
\hline Sourc: Stre & &
\end{tabular}

Source: Survey data of maize growers, 2012-13 collected by SAAO, DAE/Researcher, BARI.

There were 20 blocks under 10 unions at Pirganj upazila. Total area, production and yield of maize at this upazila were 5100 ha, $34508.75 \mathrm{t}$ and $6.77 \mathrm{t} / \mathrm{ha}$, respectively during 2012-13 (Table5). 


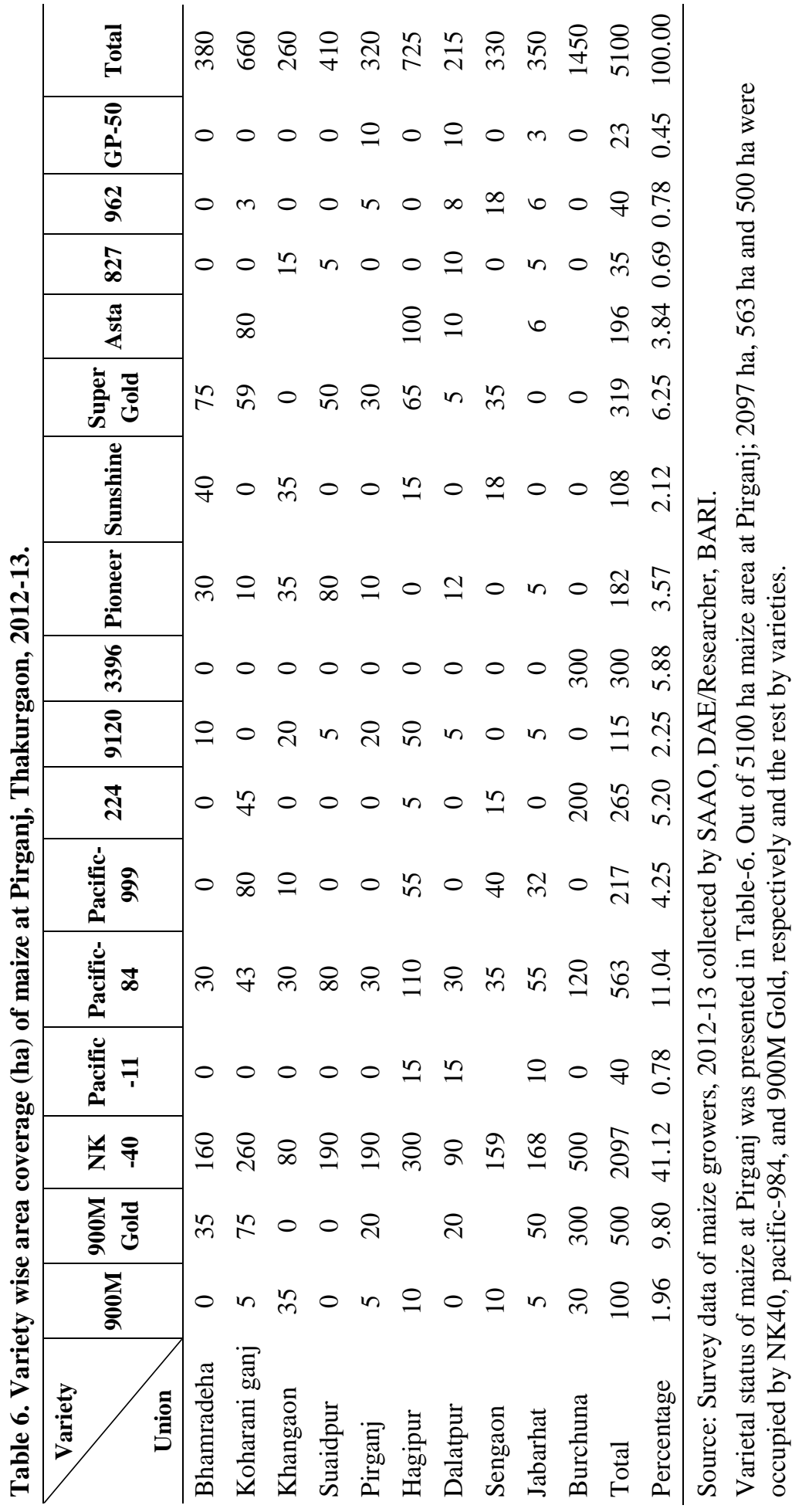


Table 8. Area (ha), production (t) and yield (t/ha) of maize at Pirganj of Thakurgaon district, respectively, 2012-13.

\begin{tabular}{l|c|c|c}
\hline Area & Area (ha) & Production (t) & Yield(t/ha) \\
\hline Pirganj (Thakorganj) & 5100 & 34508.75 & 6.77 \\
\hline
\end{tabular}

Source: Survey data of maize growers, 2012-13 collected by SAAO, DAE/Researcher, BARI.

Cultivated area of maize in the study areas was 5100 ha. production was $34508.75 \mathrm{t}$ and yield of maize was $6.77 \mathrm{t} / \mathrm{ha}$ (Table-8) at Pirganj, in Thakorganj.

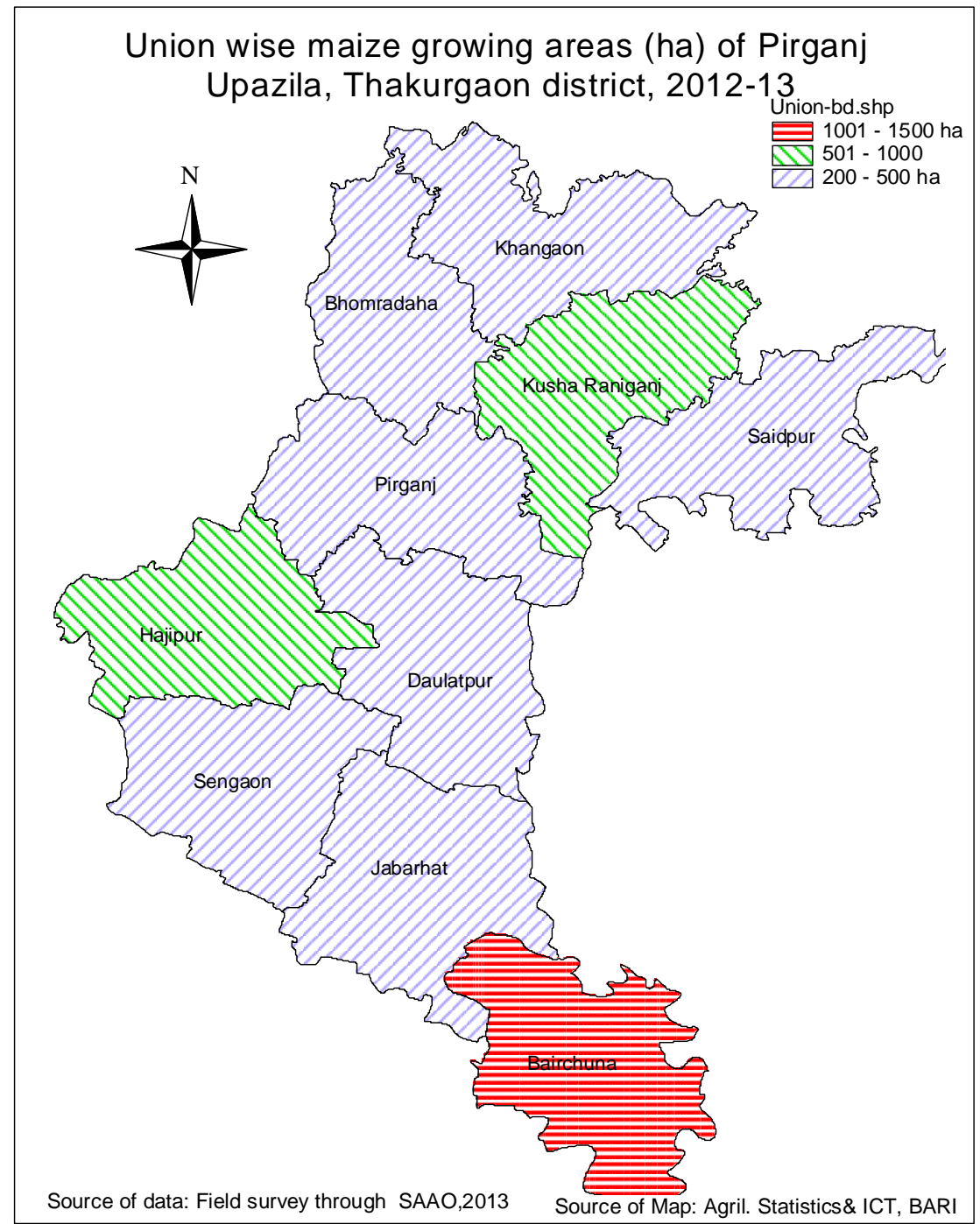

Map-1. Union wise maize growing areas (ha) of Pirganj upazila, Thakurgaon district, 2012-13. 
Table 9. Price (Tk/Kg), cost $(\mathrm{Tk} / \mathrm{Kg})$, benefit $(\mathrm{Tk} / \mathrm{Kg})$ and benefit cost ratio (BCR) of maize at Pirganj of Thakurgaon district, 2012-13.

\begin{tabular}{c|c|c|c|c}
\hline Area & Price (Tk/Kg) & Cost(Tk/Kg) & Benefit/Profit (Tk/Kg) & BCR \\
\hline Pirganj (Thakorganj) & 13.68 & 7.15 & 6.53 & 1.91 \\
\hline
\end{tabular}

Benefit Cost Ratio (BCR) of maize was 1.91 at Pirganj in Thakorganj district. (Table-9)

\section{Conclusion}

In this study, digital databases of different parameters such as area, production, yield and varietal information etc of maize were obtained. Union, upazila and district maps of maize were also developed. Sixteen (16) varieties were cultivated and Maximum area $(74.09 \%)$ of maize was cultivated by the executive varieties NK-40, Pacific-984, 900M Gold, 900M, 3396 and Super gold. A web site was developed for variety wise area coverage data collection of maize as well as for other crops. This web site can be used through mobile phone. It is noted that BARI maize varieties were not cultivated in the study areas. However, it was found in some places of Manikganj, Kushtia, Dinajpur, Chuadanga, Jamalpur and Sherpur etc. Where germination capacity of BARI maize varieties needs improvement and their cultivation must be expanded rapidly in the farmers' fields. Furthermore dwarf type maize variety should be released. Besides adopting HYVs, management practices should be improved. Finally it was revealed that enhancement of maize production could be gained by vertical and horizontal expansion.

\section{References}

BBS. (2010), The Yearbook of Agricultural Statistics of Bangladesh-2010, Bangladesh Bureau of Statistics, Statistics Division, MOP, GOB, Dhaka.

BBS. (2010), The Yearbook of Agricultural Statistics of Bangladesh-2010, Bangladesh Bureau of Statistics, Statistics Division, MOP, GOB, Dhaka.

DAE. (2010), Department of Agricultural Extension, Ministry of Agriculture, Khamar Bari, Fram Gate, Dhaka.

DAE. (2011), Department of Agricultural Extension, Ministry of Agriculture, Khamar Bari, Fram Gate, Dhaka.

UN,FAO(2009) The Food and Agriculture Organization of the UN,FAO

IITA (2009), International Institute for Tropical Agriculture

BBS.(2007), Yearbook of Agricultural Statistics of Bangladesh. Bangladesh Bureau of Statistics, Ministry of Planning, Government of the people's Republic of Bangladesh, Dhaka.

Roy, Debasis Saha (2009) Vutta neya sangram rafiqer. Special report of Saturday, Prothom Alo. 28 March. 